\title{
A hitchhiker's guide to myeloid cell subsets: practical implementation of a novel mononuclear phagocyte classification system
}

\author{
Martin Guilliams ${ }^{1,2 *}$ and Lianne van de Laar ${ }^{1,2 *}$ \\ 'Laboratory of Immunoregulation, VIB Inflammation Research Center, Ghent University, Ghent, Belgium, ${ }^{2}$ Department of \\ Respiratory Medicine, University Hospital Ghent, Ghent, Belgium
}

OPEN ACCESS

Edited by:

Ken J. Ishii,

National Institute of Biomedical

Innovation, Japan

Reviewed by:

Richard A. Kroczek,

Robert Koch-Institute, Germany Kazuhiro Suzuki,

Osaka University, Japan

*Correspondence:

Martin Guilliams and

Lianne van de Laar,

Laboratory of Immunoregulation, VIB Inflammation Research Center, Ghent University, Technologiepark 927,

Zwijnaarde, 9052 Ghent, Belgium martin.guilliams@irc.vib-ugent.be; lianne.vandelaar@irc.vib-ugent.be

Specialty section: This article was submitted to Antigen Presenting Cell Biology, a section of the journal Frontiers in Immunology

Received: 13 June 2015

Accepted: 24 July 2015

Published: 11 August 2015

Citation:

Guilliams M and van de Laar L (2015) A hitchhiker's guide to myeloid cell subsets: practical implementation of a novel mononuclear phagocyte classification system.

Front. Immunol. 6:406. doi: 10.3389/fimmu.2015.00406
The classification of mononuclear phagocytes as either dendritic cells or macrophages has been mainly based on morphology, the expression of surface markers, and assumed functional specialization. We have recently proposed a novel classification system of mononuclear phagocytes based on their ontogeny. Here, we discuss the practical application of such a classification system through a number of prototypical examples we have encountered while hitchhiking from one subset to another, across species and between steady-state and inflammatory settings. Finally, we discuss the advantages and drawbacks of such a classification system and propose a number of improvements to move from theoretical concepts to concrete guidelines.

Keywords: nomenclature, dendritic cells, macrophages, monocytes, classification

\section{Introduction}

In the science fiction series created by Douglas Adams (1), the Hitchhiker's Guide to the Galaxy starts as follows: "Space is big. Really big. You just won't believe how vastly hugely mind-boggling big it is. You may think it's a long way down the road to the chemist's, but that's just peanuts to space." Given the complexity of the mononuclear phagocyte (Star)system (MPS), one could easily give a similar warning to readers who are trying to make some sense of the huge number of hypothetically distinct dendritic cell (DC) and macrophage (M $\Phi)$ subsets. At the last International DC Symposium (DC2014, Tours - France), we counted at least 28 different DC subsets that were described using various surface markers and nomenclature systems in distinct species. If one would add the different $M \Phi$ subsets and the Cytof technology allowing to measure the expression of more than 30 different surface markers per cell, one could with a bit of luck end up with " 42 " as answer to the ultimate myeloid question of how many mononuclear phagocyte subsets exist in life, the universe, and everything. Although this would be great for fans of Douglas Adams, without Babel Fish to help us make some sense of so many different subsets, this evolution will not be beneficial for communication among myeloid cell experts, let alone for the communication toward pharmaceutical companies, scientific editors, medical doctors, or graduate students. We will here try to simplify this apparent complexity through a number of practical examples and theoretical concepts. Having hitchhiked from $M \Phi$ to DC labs studying myeloid cells in various tissues and in distinct inflammatory conditions, we would, in accordance with the Hitchhiker's Guide to the Galaxy, advise the following: do not panic and bring your towel along. 


\section{Members of the Mononuclear Phagocyte System}

In the original MPS model proposed by Ralph van Furth, James Hirsch, and Zanvil Cohn, MФs were proposed to derive from circulating monocytes (2). A couple of years later, Ralph Steinman and Zanvil Cohn identified DCs, which were also included in the MPS (3). The fact that DCs could be derived from human and mouse monocytes in GM-CSF-driven in vitro cultures (4-8) and in vivo upon inflammation or in barrier tissues (9-15) supported this concept. For a historical overview of the MPS field, we redirect the readers to the review of Simon Yona and Siamon Gordon in this issue (16). The identification of mouse hematopoietic precursors committed to the DC lineage called the common DC progenitors (CDPs - giving rise to $\mathrm{pDCs}$ and $\mathrm{cDCs}$ ) and pre$\mathrm{cDCs}$ (giving rise to $\mathrm{cDCs}$ ) that are distinct from monocytes and can give rise to the so-called conventional DCs (cDCs) induced a first conceptual revolution in the field $(12,17-20)$. Moreover, Flt3-L, and not GM-CSF, was shown to be critically involved in the development of cDCs in vitro $(8,21-23)$ and in vivo (24-28). Recently, two additional committed precursors were identified in mice: the pre-pDC precursor that preferentially differentiates into pDCs (29), and the monocyte-committed common monocyte progenitor (cMop) (30). Importantly, the human equivalent of the pre-cDC, CDP, and cMop was recently identified $(31,32)$. A second conceptual revolution in the field was driven by the finding that most tissue-resident $\mathrm{M} \Phi$ s do not derive from circulating HSC-derived monocytes but develop from embryonic

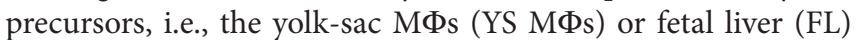
monocytes (33-39). The relative contribution of YS M $\Phi$-derived and FL monocyte-derived MФs seems to vary from one organ to another (40-42). It was recently demonstrated that almost all MФs have a YS origin [either directly from YS MФs or through YS-derived EMPs (39)]. This may seem in contradiction with the proposed partial origin from FL monocytes $(35,43)$. However, it is now clear that YS-derived EMPs seed the FL and go through a FL monocyte intermediate before differentiating into most tissueresident MФs (44), reconciling most of the apparent discrepancies in the field. Together, these findings have challenged the MPS dogma and revealed that most DCs and MФs derive from distinct committed precursors rather than from circulating HSC-derived monocytes (Figure 1).

\section{Revisiting the Classification of Mononuclear Phagocytes}

Historically, mononuclear phagocytes were classified as DCs or M $\Phi$ s based on a restricted set of surface markers (CD11c and MHCII for DCs versus F4/80 for MФs), proposed functional specialization (antigen-presentation and migration to lymph nodes for DCs versus phagocytosis for MФs) and/or morphological features (dendritic-shaped cells for DCs versus large vacuolar cells for M $\Phi$ s). However, these features are often not mutually exclusive. For example, although CD11c and MHCII are typically associated with DCs, alveolar $M \Phi$ are CD $11 c^{\text {hi }}$ and MHCII is expressed by intestinal MФs $(35,45)$. Ideal surface markers allowing identification of the distinct myeloid cell subsets across tissues and species are still incomplete. Markers typically associated with some myeloid cell subsets can be lost or acquired by other subsets. The monocyte-associated

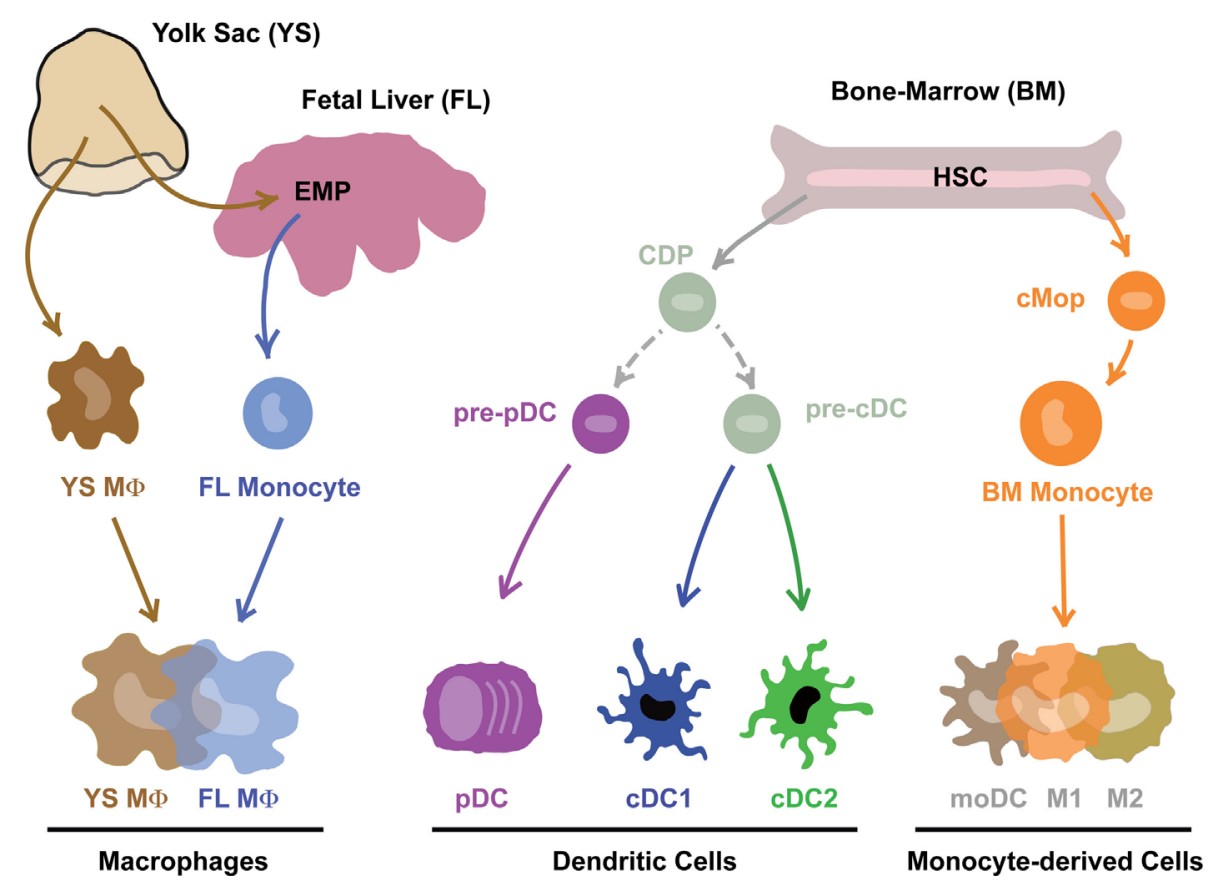

FIGURE 1 | Mononuclear phagocytes and their precursors. Note that this is work in progress and technical advances such as single-cell RNASeq and barcoding will in the near future prove or disprove many aspect of this theoretical scheme. 
marker Ly-6C is rapidly down-regulated on many monocytederived cells (MCs) upon entrance in the tissues (45-48) and is expressed on pDCs (and lowly expressed on some cDCs). The pDC-associated marker mPDCA1 (stained with 120G8) can be acquired by MCs during inflammation (49). Alveolar MФs (50) and Kupffer Cells (unpublished data) can upregulate CD11b during inflammation. Finally, BDCA3 is expressed on both human $\mathrm{CDC} 1 \mathrm{~s}$ and MCs (51). Thus, the inability to consistently identify myeloid cell subsets irrespective of tissue, species, or inflammatory state makes surface markers unattractive as basis for classification.

We would also propose to avoid a classification based primarily on functional specialization. First, each myeloid cell subset can perform more than one prototypical function. MФs are often linked to phagocytosis of dead cells and pathogens but also have important immunomodulatory and metabolic functions. Second, subsets can acquire or lose functional capacities during inflammation as recently demonstrated for $\mathrm{cDC} 2 \mathrm{~s}$ that acquire crosspresentation capacities upon TLR stimulation (52). Therefore, we propose to disregard function as a basis for classifying cells.

Instead of surface markers, functional specialization, or morphology, we have recently suggested to classify cells based on their cellular origin, which could allow a more robust classification system (53). This would yield three big groups of cells (Figure 1): (i) embryonic progenitor-derived MФs, (ii) CDP-derived DCs (that would be subdivided into $\mathrm{cDC} 1 \mathrm{~s}, \mathrm{cDC} 2 \mathrm{~s}$, and $\mathrm{pDCs}$ ), and (iii) MCs. As these precursors have now been identified in both the mouse and the human, this allows one classification system across tissues and species.

Although precursor-based classification would provide a robust and species-conserved system, at the end of the day the function of the cells is what really matters for converting our knowledge into therapeutic advances for patients. Regrouping all the DCs into three big subsets of $\mathrm{cDC} 1 \mathrm{~s}, \mathrm{cDC} 2 \mathrm{~s}$, and $\mathrm{pDCs}$ will thus have the disadvantage of lumping together cells that may be in very different functional activation states. Similarly, MCs have been shown to be particularly plastic cells (54). Therefore, we propose to add a second classification level to the fixed ontogeny-based Level1 (Figure 2). Addition of a Level2 allows specification of the cellular activation state, the micro-anatomical localization or simply the surface markers utilized to identify the cells in a particular study. Of note, when defining the Level2 it will be important to avoid generalizations as a given function is often performed by only a fraction of the cells studied. We would thus propose to restrict the Level 2 to objective criteria that can be measured at the single-cell level.

\section{Practical Implementation for DCs}

Historically, DCs were divided into subsets based on surface markers that differed between tissues and species, such as CD207 (Langerin) in the skin, CD103 (Integrin $\alpha \mathrm{E}$ ) in the intestine, $\mathrm{CD} 11 \mathrm{~b}$ (Integrin $\alpha \mathrm{M})$ in the lungs, CD4/CD8 $\alpha$ in the spleen, and CD24/CD172 $\alpha$ for in vitro differentiated DCs (Figure 3). Human DCs, on the other hand, have been divided into CD141 ${ }^{+}$(BDCA3) and $\mathrm{CD}_{1 \mathrm{c}^{+}}$(BDCA1) DCs. pDCs are identified by the expression of BDCA4 and BDCA2 in human, but by B220, mPDCA1 (BST2, recognized by 120G8), or Siglec-H in mice (53). Technical advances in multi-color flow cytometry have made matters worse with evermore "novel DC subsets" based on the expression of additional surface markers. By comparing the gene-expression profile of DCs isolated from various tissues and species, one can appreciate three big clusters of DCs (55-61). The pDC cluster includes mouse $\mathrm{PDCA}^{+} \mathrm{pDC}$ and human $\mathrm{BDCA} 2^{+} \mathrm{BDCA} 4^{+}$ pDCs. The cDC1 cluster comprises dermal $\mathrm{CD} 207^{+} \mathrm{CD} 103^{+}$ cDC1s, lung $\mathrm{CD} 103^{+} \mathrm{CD} 11 \mathrm{~b}^{-} \mathrm{cDC} 1 \mathrm{~s}$, splenic CD8 $\mathrm{a}^{+} \mathrm{CD} 4^{-} \mathrm{cDC} 1 \mathrm{~s}$, intestinal $\mathrm{CD}_{103}{ }^{+} \mathrm{CD} 11 \mathrm{~b}^{-} \mathrm{cDC} 1 \mathrm{~s}$ and human blood $\mathrm{BDCA3}^{+}$ cDC1s. Dermal CD207-CD11b ${ }^{+}$cDC2s, lung CD103-CD11b ${ }^{+}$ cDC2s, splenic CD8a ${ }^{-} \mathrm{CD} 4^{+} \mathrm{cDC} 2 \mathrm{~s}$, intestinal $\mathrm{CD} 103^{+} \mathrm{CD} 11 \mathrm{~b}^{+}$ cDC2s and human blood $\mathrm{BDCA}^{+}{ }^{+} \mathrm{CDC} 2 \mathrm{~s}$ form the $\mathrm{cDC} 2$ cluster $(62,63)$. This bio-IT-driven analysis also revealed that within the $\mathrm{cDC}$ population, XCR1 and Sirp $\alpha$ are, respectively, expressed by all $\mathrm{cDC} 1 \mathrm{~s}$ and $\mathrm{cDC} 2 \mathrm{~s}$ across tissues, allowing an improved identification of these cells $(51,64-70)$. Note, however, that Sirp $\alpha$ is also expressed by other myeloid cells than cDC2s, showing the need for correct $\mathrm{cDC}$ identification prior to using this marker to distinguish $\mathrm{cDC} 2 \mathrm{~s}$ from $\mathrm{CDC} 1 \mathrm{~s}$. Strikingly, this gene-expression-based division is supported by the existence of distinct pre-committed precursors $(29,71,72)$ and by differential developmental transcription factor requirement of $\mathrm{cDC} 1 \mathrm{~s}$,

\section{General rule: LEVEL1 trumps the LEVEL2}

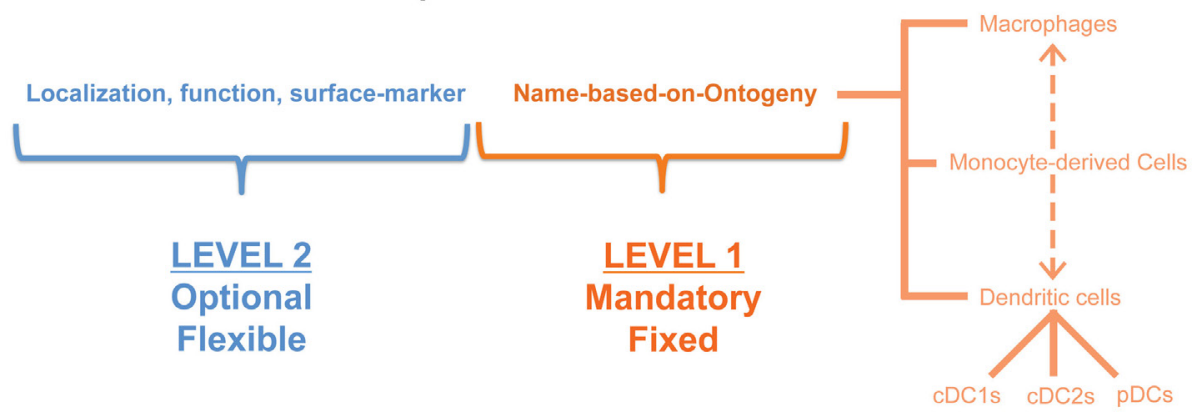

FIGURE 2 | A nomenclature system in two levels would have the advantage that cells can be first classified based on a restricted set of names (in this proposition according to their cellular origin: $\mathbf{М Ф , ~ M C , ~}$
cDC1, cDC2, pDC) that would be applicable across species and across tissues, but the second level would still allow some flexibility to denote a distinct activation state or localization. 


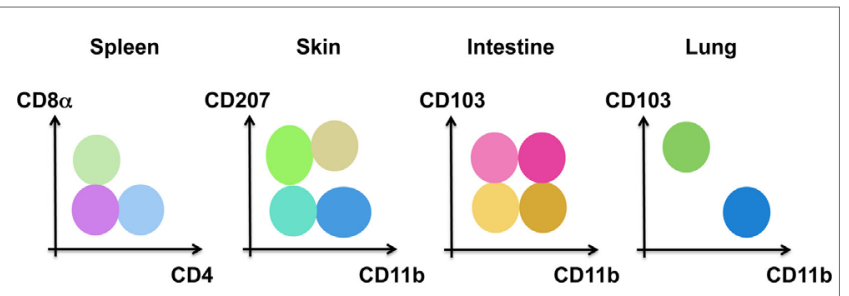

Additional markers: CD24, CD172 $\alpha$, XCR1, DNGR1, Epcam, Esam ...

FIGURE 3 | Murine DCs have been subdivided into many different subsets based on distinct surface markers in the spleen, the skin, the intestine, and the lung.

cDC2s, and $\mathrm{pDCs}$ in the mouse. $\mathrm{cDC} 1 \mathrm{~s}$, but not $\mathrm{cDC} 2 \mathrm{~s}$, require BATF3 $(71,73,74), \operatorname{ID} 2(28,75,76)$, NFIL3 (77), and IRF8 (28, $71,78-80)$ for their development, while $\mathrm{cDC} 2 \mathrm{~s}$, but not $\mathrm{cDC} 1 \mathrm{~s}$, are dependent on RELB (81), RBPJ (82), and IRF4 (79, 83-85). pDC development has been shown to be driven by E2-2 $(86,87)$.

The subdivision of DCs in three distinct Level1 groups is thus supported by their gene-expression profiles, cellular origin, and transcription factor requirement. However, these cells can acquire a distinct functional activation state from one tissue to another and in distinct inflammatory settings, underlining the need for a Level 2 system. This can be illustrated by the capacity of intestinal $\mathrm{cDC}$ to produce retinoic acid and promote the generation of induced regulatory $\mathrm{T}$ cells ( $\mathrm{iT}_{\mathrm{REGs}}$ ) (88-91). Identification of DCs with superior $\mathrm{iT}_{\mathrm{REG}}$ inducing ability is clinically relevant as the prevalence of food allergies, celiac disease and inflammatory bowel diseases is currently rising throughout the western world. Originally, it was described that $\mathrm{CD}_{103}{ }^{+}$but not $\mathrm{CD}_{103^{-}}$intestinal DCs excel in $\mathrm{iT}_{\mathrm{REG}}$ generation in a retinoic acid-dependent manner $(89,90)$. It is now clear that CD103+ intestinal DCs comprise two ontogenically distinct subsets, $\mathrm{CD} 103^{+} \mathrm{CD} 11 \mathrm{~b}^{-} \mathrm{cDC} 1 \mathrm{~s}$ and $\mathrm{CD} 103^{+} \mathrm{CD} 11 \mathrm{~b}^{+} \mathrm{cDC} 2 \mathrm{~s}(74)$. Interestingly, rather than being associated with either of the two subsets, about half of the intestinal $\mathrm{CD} 103^{+} \mathrm{CD} 11 \mathrm{~b}^{-} \mathrm{cDC} 1 \mathrm{~s}$ were shown to possess the capacity to produce retinoic acid, while only one-third of the $\mathrm{CDC} 2 \mathrm{~s}$ do (91). Moreover, on a per cell basis retinoic acid producing $\mathrm{CD} 103^{+}$ $\mathrm{cDC} 1 \mathrm{~s}$ were the best at inducing $\mathrm{iT}_{\mathrm{REGs}}$ (Figure 4). These data reveal that $\mathrm{CD} 103^{+} \mathrm{cDC} 1 \mathrm{~s}$, although broadly considered as a homogeneous subset, consist of $50 \%$ cells that are very efficient at inducing $\mathrm{iT}_{\mathrm{REGs}}$ and $50 \%$ cells that are not. Interestingly, dermal cDC2s have higher retinoic acid-dependent $\mathrm{iT}_{\mathrm{REG}}$ induction activity than dermal cDC1s (91). We hypothesize that this functional heterogeneity may be explained by the existence of distinct micro-environments within organs, inducing diverse functional modules on DCs. The finding that important functional modules can be acquired by only a fraction of CDC1s and/or cDC2s, which can moreover differ from one organ to another, illustrates the need for a Level2 nomenclature for DCs.

Another example of functional heterogeneity within DCs concerns the cDC2s. Splenic cDC2s contain a subpopulation that expresses CD4 and is specifically localized in the bridging channels (92). This localization has been shown to be EBI2-driven and essential to drive antibody production by B cells. The development of these $\mathrm{CD} 4^{+} \mathrm{cDC} 2 \mathrm{~s}$ is Notch2 dependent. Note also that
Notch2 deficiency is associated with defects in $\mathrm{T}_{\mathrm{H}} 17$ induction $(93,94)$. In addition, it was found that KLF4 controls the development of a subpopulation of CD $24^{\text {lo }} \mathrm{CD} 11 \mathrm{~b}^{\text {lo }} \mathrm{Sirp} \alpha^{\text {hi }} \mathrm{cDC} 2 \mathrm{~s}$ in the dermis (95). Importantly, loss of KLF4 was associated with loss of $\mathrm{T}_{\mathrm{H}} 2$ induction. Thus, although $\mathrm{CDC} 2 \mathrm{~s}$ have been proposed to excel at both the induction of $\mathrm{T}_{\mathrm{H}} 2(47,96)$ and $\mathrm{T}_{\mathrm{H}} 17$ responses $(84,85,93)$, it may well be that these functional modules are in fact expressed by subpopulations of cDC2s (controlled by KLF4 and Notch2, respectively). In conclusion, although the current knowledge of early DC development in the bone-marrow seems to support only three big groups of DCs ( $\mathrm{cDC} 1 \mathrm{~s}, \mathrm{cDC} 2 \mathrm{~s}$, and pDCs), it appears that a second layer of tissue-specific signals imprint operative gene modules on a fraction of DCs. Depending on their micro-localization, subpopulations of $\mathrm{cDC} 1 \mathrm{~s}, \mathrm{cDC} 2 \mathrm{~s}$, or pDCs will acquire distinct functional properties, requiring a flexible Level 2 to classify and describe functionally distinct subpopulations.

A final example of a need for a Level 2 classification involves inflammation-induced changes of surface marker expression. When mice are infected with the influenza virus, there is a transient change in the CD103 versus CD11b expression profile of lung cDCs, yielding four instead of two lung DC subsets (Figure 5). If one considers these as four distinct DC subsets, one could conclude that influenza infection disrupts hematopoiesis in the bone-marrow, as has been shown for Toxoplasma infection (97). Alternatively, these novel CD103/CD11b expression patterns may represent distinct local activation states of $\mathrm{CDC} 1 \mathrm{~s}$ or cDC2s. We have studied the cellular origin of the "novel" DC subsets arising during influenza infection (Neyt et al., manuscript in preparation). Our preliminary data suggest that $\mathrm{CD} 103^{+} \mathrm{CD} 11 \mathrm{~b}^{+}$ cells are $\mathrm{cDC} 2 \mathrm{~s}$ that acquire CD103 expression during inflammation rather than a completely new subset. In conclusion, although we cannot rule out the existence of additional DC subsets that specifically develop during inflammation, when in doubt we propose to first evaluate whether cells with a novel surface receptor expression profile represent a different activation state of $\mathrm{cDC} 1 \mathrm{~s}$ or $\mathrm{cDC} 2 \mathrm{~s}$ before assuming the existence of a novel $\mathrm{cDC} 3$.

\section{Practical Implementation for Embryonic Macrophages}

In our classification system based on ontogeny all mononuclear phagocytes of embryonic origin are grouped together under a single Level1 as "macrophages" (Figure 1). This includes liver-resident Kupffer cells, brain-resident microglial cells, lungresident alveolar $\mathrm{M} \Phi$ s but also epidermis-resident Langerhans cells. In effect, this would thus classify Langerhans cells as MФs and not as DCs, based on the fact that these cells derive from embryonic precursors that seed the epidermis around birth and then self-maintain throughout life $(43,98)$. We propose to keep the historical names for MФs with undisputed identities. Mouse Kupffer cells, for example, do not require a different nomenclature since these cells have a well-defined cellular origin [embryonic $(34,38,39)$ ], localization (i.e., the liver sinusoids), and gene-expression profile (99, 100). However, we would like to emphasize that not any $\mathrm{F} 4 / 80^{+}$cell in the liver should be categorized as Kupffer cell. MCs infiltrating 


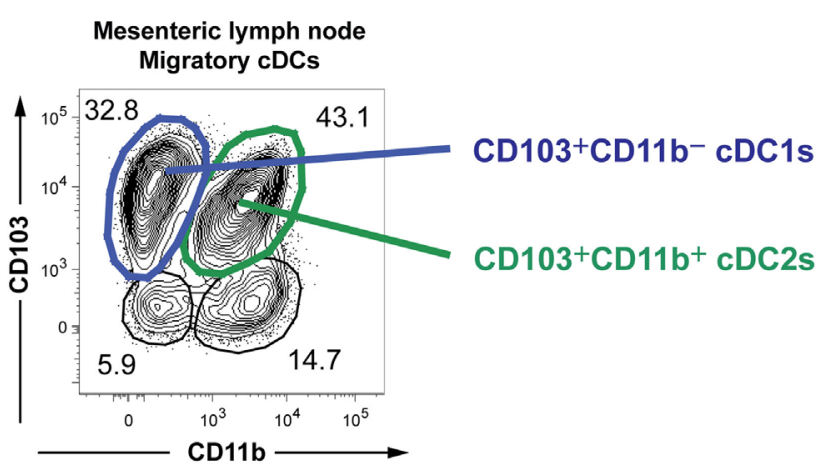

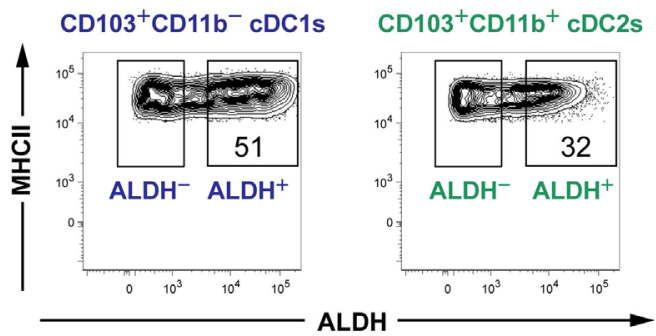

FIGURE 4 | Existence of subpopulations with distinct retinoic acidproducing capacities within both $\mathrm{CDC} 1 \mathrm{~s}$ and $\mathrm{CDC} 2 \mathrm{~s}$ in the mesenteric lymph nodes of mice. The capacity to produce retinoic acid was measured

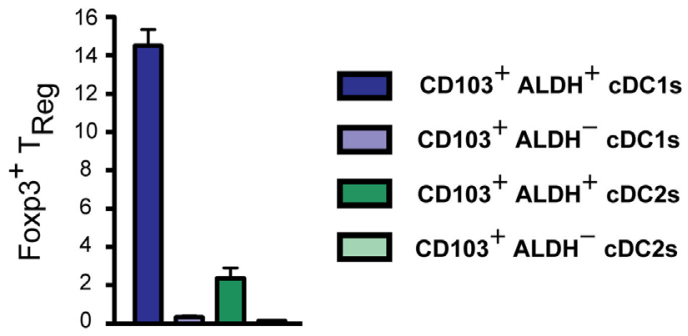

by the Aldefluor kit (91). DCs were sorted, loaded with the ovalbumin-peptide, and co-cultured in vitro with naïve OTII cells to measure the induction of Foxp3 on these cells. the liver during acetaminophen-induced injury also express F4/80 but are short-lived and acquire a gene-expression profile that is strikingly different from resident Kupffer cells (100). Similarly, MCs infiltrating the central nervous system during inflammation are short-lived and do not acquire the specific gene-expression profile of embryonic microglia (101-103). As such, any $M \Phi$-like cell in the liver or the brain should not be classified as Kupffer cell or microglia, respectively, as is often the case. Unfortunately, tools to correctly distinguish MCs from resident $M \Phi$ s have long been lacking. In a way, this is surprising given the huge difference in gene-expression profile between resident embryonic MФs and recruited MCs in these disease models. We have now identified several surface markers that are expressed by Kupffer cells but not MCs recruited during liver injury (Scott et al. manuscript in preparation) and we expect that given the striking heterogeneity of tissue-resident MФs $(104,105)$ many of these $M \Phi$-specific markers will be found. This will facilitate the correct classification of these cells and pave the way toward unraveling the functional differences between recruited MCs and tissue-resident embryonic MФs during inflammation.

\section{Practical Implementation for Monocyte-Derived Cells}

Monocytes are particularly plastic cells. This can be appreciated using in vitro culture systems. Monocytes cultured with GM-CSF express some DC-like characteristics and have therefore long been referred to as moDCs. By contrast, culturing monocytes with M-CSF induces their differentiation into MФ-like cells (moMФs). Adding IL-4 or IFN- $\gamma$ to M-CSF cultures further polarizes MCs into the so-called "classically

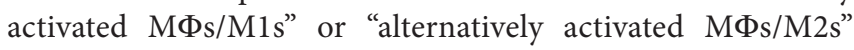
(106), with strikingly different gene-expression profiles and metabolic modules (107). In a nomenclature system based on ontogeny, moDCs, M1s, or M2s are however first classified as MCs (Level1). In theory, this does not prevent further Level2 classification as "dendritic MCs," "classically activated MCs," or "alternatively activated MCs." However, we feel this polarized classification implies functional characteristics that are often not assessed experimentally. For example, MCs classified as M1s are typically associated with pathogen killing, M2s with wound healing, and moDCs with antigen-presentation (Figure 6). However, the identification of "dendritic MCs/moDCs," classically activated MCs/M1s," or "alternatively activated MCs/M2s" in vivo turned out to be very challenging. In fact, profiling of MCs isolated from various inflamed tissues or in vitro culture systems reveals that monocytes can acquire a much broader transcriptional repertoire than suggested by the three-way M1/ $\mathrm{M} 2 /$ moDC model. In recent efforts to further characterize the heterogeneity of MC activation states, Schultze and colleagues compared the gene-expression profile of MCs stimulated with a vast array of cytokines and TLR ligands. Instead of yielding a polarized model, the unbiased bio-informatics-driven clustering approach revealed a spectrum model (54). In our view, this spectrum model can be taken one step further and include the "dendritic MCs/moDCs" derived from GM-CSF-induced bone-marrow cultures as yet another extreme of the continuum of cellular faiths that can be acquired by monocytes. Rather 

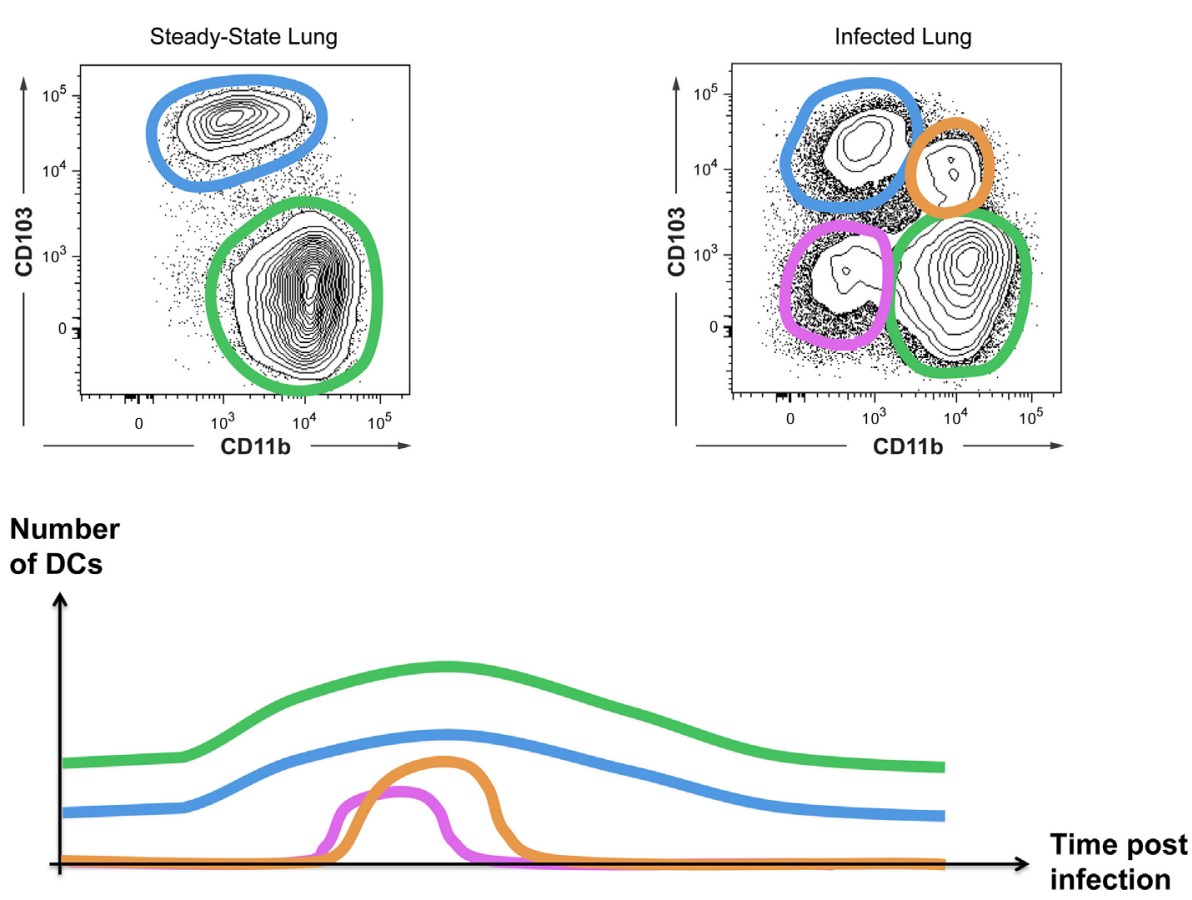

FIGURE 5 | Inflammation can induce the appearance of "novel" DC subsets. CD103 and CD11b expression on cDCs from uninfected or influenza-infected lungs are shown. The appearance of CD103+CD11 b+ DCs and CD103-CD11 b- DCs is transient as schematically represented.

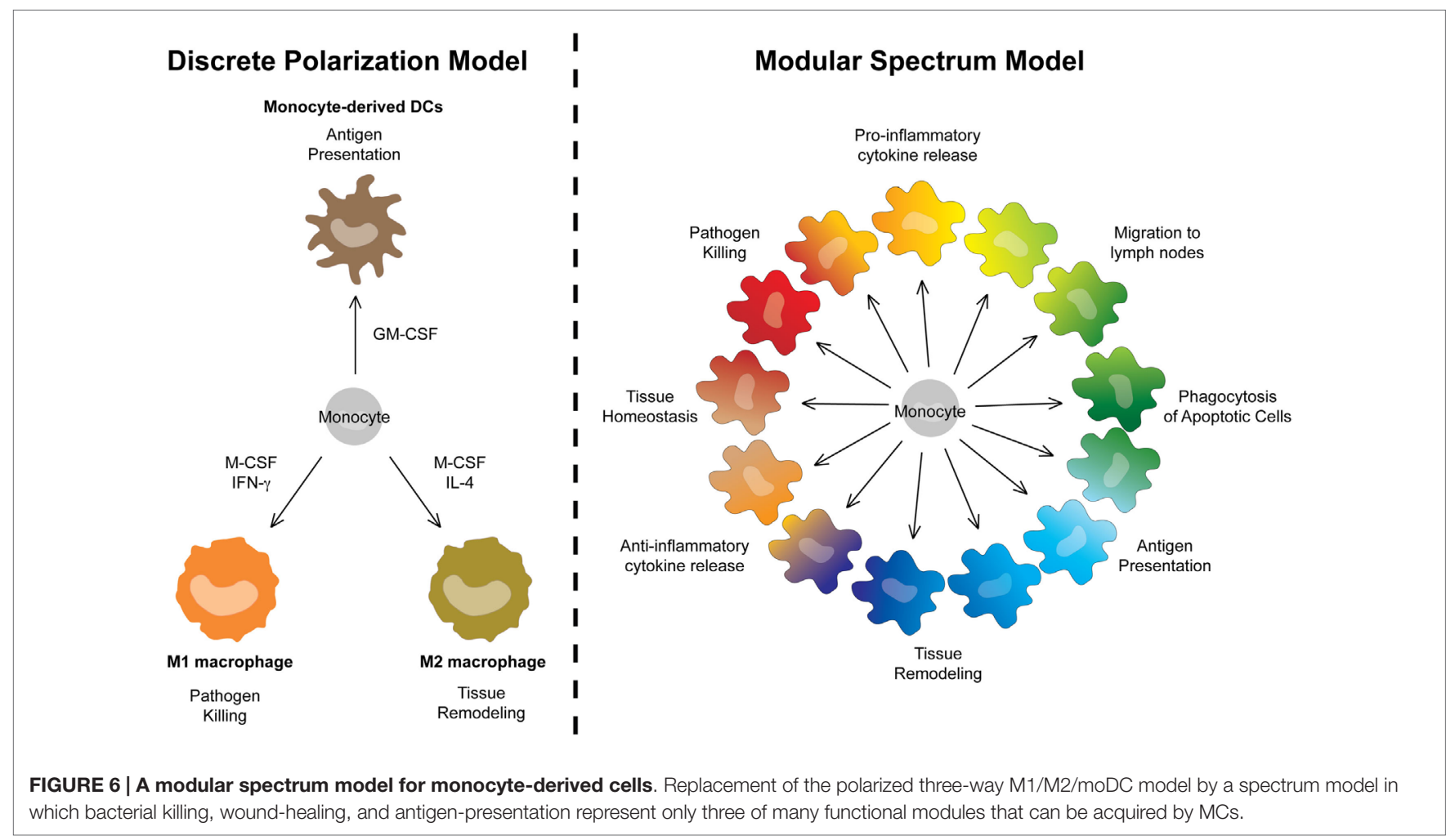

than unique end points, bacterial killing, wound-healing, and antigen-presentation represent three of many functional modules that can be acquired by MCs in a spectrum model that can be graphically represented by a continuous circle (Figure 6).
One important consequence of the herein-described classification would be the regrouping of moDCs and moMФs under a single MC Level1. We feel this will represent an improvement for the field due to the lack of clear, mutually exclusive features 


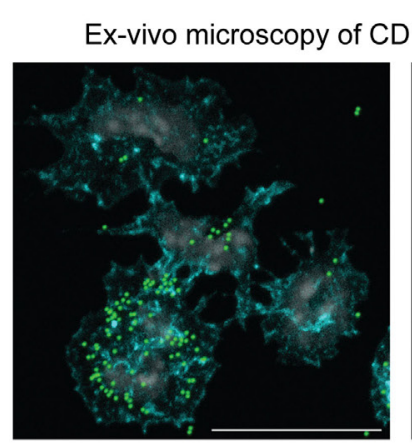

Blue $=$ Actin

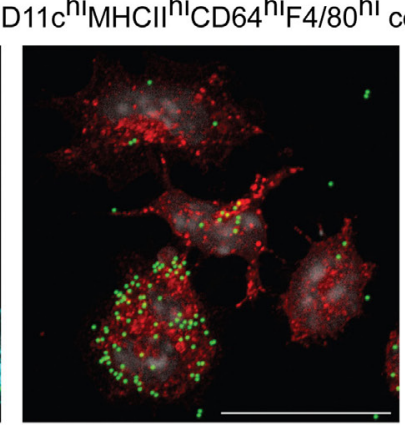

Red $=\mathrm{MHCII}$

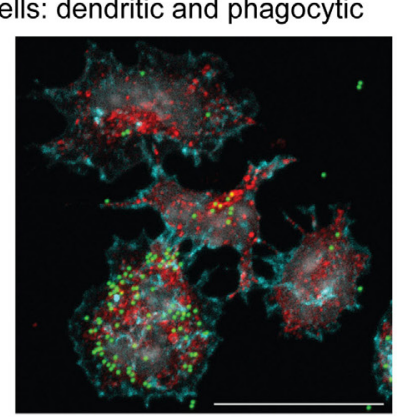

Green $=$ Latex Beads

FIGURE 7 | Microscopic characterization of MCs isolated from inflamed mesenteric lymph nodes in an experimental model for colitis $\mathrm{CD} 11 \mathrm{C}^{\mathrm{hi}} \mathrm{MHCI}{ }^{\text {hi }} \mathrm{CD} 64^{\mathrm{h}} \mathrm{F} 4 / 80^{\text {hi }}$ cells were sorted and cultured in vitro to evaluate their morphology and capacity to phagocytose latex beads (45).

that can be used to objectively separate moDCs from moMФs (53). This problem can be illustrated by the MCs present within inflamed mesenteric lymph nodes during an experimental model for colitis (45). In this study, we called these cells moMФs because they were CD64 ${ }^{\text {hi }} \mathrm{F} 4 / 80^{\mathrm{hi}}$ and excelled at phagocytosis (Figure 7). However, we could perfectly, like the Powrie group (108), have classified these cells as moDCs based on their CD11 $c^{\text {hi }}$ MHCII ${ }^{\text {hi }}$ profile, their localization within the $\mathrm{T}$ cell zone, their antigenpresentation capacity, or their dendritic morphology (Figure 7). By classifying these cells as CD $64^{\text {hi }} \mathrm{F} 4 / 80^{\text {hi }}$ and/or CD $11 c^{\text {hi }} \mathrm{MHCII}^{\text {hi }}$ MCs, they are recognized as one lineage, which will promote understanding and simplify communication between different research groups without preventing the study of DC-like or MФlike properties of specific MCs.

Finally, we do not expect MCs to be homogeneous in inflamed tissues. We and others found iNOS, the enzyme that is used by MФs to produce NO and that is classically associated with an M1 activation state, to be typically expressed by only $10 \%$ of MCs (11, $45,109)$. Since NO is bactericidal, suppressive for T cells, and can induce serious tissue damage, it makes perfect sense to study the factors that induce the expression of iNOS on a fraction of MCs. But by classifying these cells as "iNOS ${ }^{+}$MCs" instead of "M1 macrophages" or "TIP-DCs" one avoids to associate functions that have not been proven for these cells such as the antigenpresentation activity typically expected from DCs [in fact mice lacking monocytes showed identical $\mathrm{T}$ cell priming suggesting that TIP-DCs are not essential for this function (11)].

\section{The Tough Cases Part I: moDCs as Fourth DC Subset?}

MCs fitting the complete list of characteristics attributed to moDC, including migratory and antigen-presentation capacities comparable to cDCs, are not easily identified in vivo. We have described migratory MCs upon house-dust mite (HDM) exposure in the lungs (47), but their migration is much less efficient as compared to $\mathrm{CDCs}$ and required very high (and non-physiological) doses of HDM. In fact, we found that the majority of HDM-induced pulmonary MCs are not migratory cells but instead play an important role in the secretion of inflammatory chemokines that orchestrate the local immune responses. Similarly, a low-grade migration of $\mathrm{CCR} 2^{+} \mathrm{CD} 64^{\text {int }}$ MCs was described upon DSS inflammation in the skin but this was minor as compared to cDC migration (48). Moreover, compared to cDCs these dermal $\mathrm{CCR} 2{ }^{+} \mathrm{CD} 64^{\text {int }} \mathrm{MCs}$ displayed a rather modest antigen-antigen presentation capacity.

The most convincing pieces of evidence for cDC-like features of MCs come from in vitro culture systems. Bone-marrow cells cultured with GM-CSF yield cells with excellent antigenpresentation capacity that acquire CCR7, the chemokine receptor controlling migration of cDCs from tissues to lymph nodes, upon TLR stimulation and can migrate to the lymph nodes upon in vivo transfer $(110,111)$. This culture system has been used in many labs and is globally accepted to yield a homogeneous population of moDCs. This concept was first challenged by a study using single-cell transcriptomics (112). Among LPS-stimulated GM-CSF-induced bone-marrow-derived moDCs, the majority of cells were found to show high expression of inflammatory genes such as TNF, IL1, and CXCL10, while a smaller subset had much lower expression of these genes but displayed a signature reminiscent of "mature DCs", including high expression of CCR7 (113, 114). This was originally interpreted as functional heterogeneity among moDCs. However, in what we consider a landmark paper, Reis e Sousa and colleagues now demonstrate that this minor "mature" population in fact represents $\mathrm{CDC} 2 \mathrm{~s}$ that contaminate these cultures. These cDC2s displayed lower production of inflammatory cytokines but much better CCR7-ligand-induced migration and antigen-presentation as compared to GM-CSF-induced MCs $(115,116)$. This implies that many of the DC-like features of GM-CSF-induced moDCs should in fact not be attributed to MCs, but to a minor contaminating CDC2 population. All in all, both in vitro and in vivo data thus point toward a lower migration and antigen-presentation capacity of MCs as compared to cDCs, but conversely a higher production of inflammatory cytokines and chemokines. We therefore propose that in an inflamed organ the core business of $\mathrm{cDCs}$ will be migration to the draining lymph nodes and activation of naïve T cells, whereas MCs will primarily 
orchestrate local inflammatory responses. Note that this has important consequences for DC-based vaccination strategies as this may explain why MC-based vaccines have only yielded modest clinical responses (117). The recent advances in $\mathrm{cDC}$ culture systems and the proper identification of committed circulating DC-precursors $(31,32,118)$ may therefore pave the way toward more efficient $\mathrm{cDC}$-based vaccination strategies.

\section{The Tough Cases Part II: Steady-State MCs Versus Embryonic Macrophages}

Most MФ-like cells present in steady-state tissues are of embryonic origin $(33-36,38,39,44)$. However, puzzling exceptions have been reported. Although embryonic MФs colonize the intestine and the heart before birth, these cells are thereafter progressively replaced by MCs. Importantly, these cells are relatively short-lived and continuous monocyte-recruitment is required to maintain the MC pool in these tissues (45, 46, 119-121). Similarly, monocytes are continuously recruited to the steady-state dermis (48). Therefore, while in some steady-state tissues, including the lung and the spleen, monocytes have been proposed to remain in an undifferentiated state $(37,122)$; in others, including the intestine, the skin, and the heart, they acquire a $М \Phi$-like phenotype. The classification of MCs that differentiate in these steady-state organs and that replace the embryonic $M \Phi s$ is difficult. They do not fit the profile of the MCs that are recruited to inflamed tissues, including pulmonary infection (36), auto-immune brain inflammation $(101,102)$, and acute liver injury (100), since in these inflammatory settings MCs do not replace the embryonic $M \Phi$ s and display a very different gene-expression profile. Future research will be required to compare the functional properties and gene-expression profile of the embryonic MФs present in the intestine, the skin, and the heart to the ones from the MCs that replace them with time. It will be interesting to compare the influence of tissue-imprinting to the intrinsic differences associated with their distinct cellular origin. Embryonic MФs were recently compared to their bone-marrow-derived counterparts that replace them after irradiation-induced depletion. It was found that both cells share between 50 and $90 \%$ of the tissue-specific epigenetic landscape (105). This emphasizes the importance of tissue-imprinting, but at the same time implies that between 10 and $50 \%$ of the epigenetic landscape could be governed by the cellular origin of the cells. Future research will be required to assess the functional relevance of these findings. In the meantime, the classification of $M \Phi$-like MCs in steady-state tissues remains difficult.

\section{The Way Forward}

The Level1 that forms the scaffold of the herein proposed classification system is in part based on elegant murine fate-mapping systems developed to study the cellular origin of MФs $(33,34$, $38,39,43,44)$ and DCs [(123) and (124) in this issue]. Although the recent identification of committed DC-precursors distinct from monocytes in humans suggests that many of the principles identified in mice apply to the human immune system, this remains to be formally proven. Moreover, many of these murine fate-mapping systems label only a small fraction of the cells per population, rendering functional studies difficult. In cases where classification as $\mathrm{CDC} 1, \mathrm{cDC} 2, \mathrm{pDC}, \mathrm{MC}$, or $\mathrm{M} \Phi$ is not obvious, a core set of signature genes that are specific for each cell type could facilitate correct Level1 identification. However, such signature genes are not easily identified. In addition, identification based on surface receptors would be most practical since it would allow the sorting of living cells through flow cytometry for functional assays. Ideally, such markers would be conserved across species. We are currently data-mining the gene-expression profiles of cells from various tissues and species to try to identify such markers. This can however represent a catch22. To find markers specifically expressed by the different populations, one requires pure geneexpression profiles, but correct sorting of the cells without contamination by other populations for RNA profiling requires the very markers we are looking for. Recent technological advances in single-cell RNA sequencing will allow to profile the gene expression of mixed populations. This may at last disentangle mixed myeloid populations and will hopefully provide the field with new markers that can then be validated with the current fate-mapping systems.

Although the current classification systems should thus be seen as work in progress, we are confident that in the near future better markers will be found which faithfully translate the cellular origin of cells and will form a practical base for the Level1 classification of myeloid cells. The Level 2 classification should in our view be kept as flexible as possible to allow researchers to focus on one particular functional attribute of their cells of interest without implying too many additional features that have not been studied. Finally, it is noteworthy that in parallel to our proposition a nomenclature system for MФs was proposed (106). In this proposition, terms implying functional specialization such as "classically activated macrophages" (pro-inflammatory) or "alternatively activated macrophages" (anti-inflammatory) were replaced by an objective description of how a $M \Phi$ is cultured in vitro [e.g., $\mathrm{M} \Phi$ (IL-10)] or identified in vivo (e.g., "Relma ${ }^{\text {hi }}$ $M \Phi$ "). Thus, the common core Levell would be $M \Phi$ and the added description provides the Level2. This and our classification system thus share three important principles: (i) elimination of terms that imply functional specialization as much as possible, (ii) introduction of a fixed Level1 system across species and tissues, and (iii) permitting flexibility through a Level 2 system. Irrespective of which system is used to define the Level1 [ontogeny as we propose, or gene-expression profile as proposed by the Dalod group in this issue $(60,61)]$, we feel these three principles should be maintained for a future and hopefully definitive classification system.

\section{Acknowledgments}

We thank Bernard Malissen, Hugues Lelouard, Bart Lambrecht, and Katrijn Neyt for the use of unpublished data. MG is supported by a Marie Curie Reintegration grant, an Odysseus grant, and several FWO grants of the Flemish Government. LL is supported by an EMBO long-term fellowship and a Marie Curie intra-European fellowship. 


\section{References}

1. Adams D. The Hitch Hiker's Guide to the Galaxy. London: Pan Books (1979).

2. van Furth R, Cohn ZA, Hirsch JG, Humphrey JH, Spector WG, Langevoort HL. [Mononuclear phagocytic system: new classification of macrophages, monocytes and of their cell line]. Bull World Health Organ (1972) 47:651-8.

3. van Furth R. "Identification of Mononuclear Phagocytes: Overview and Definitions," in Methods for Studying Mononuclear Phagocytes. London: Academic Press (1980). p. 243-52.

4. Inaba K, Inaba M, Romani N, Aya H, Deguchi M, Ikehara S, et al. Generation of large numbers of dendritic cells from mouse bone marrow cultures supplemented with granulocyte/macrophage colony-stimulating factor. J Exp Med (1992) 176:1693-702. doi:10.1084/jem.176.6.1693

5. Sallusto F, Lanzavecchia A. Efficient presentation of soluble antigen by cultured human dendritic cells is maintained by granulocyte/macrophage colony-stimulating factor plus interleukin 4 and downregulated by tumor necrosis factor alpha. J Exp Med (1994) 179:1109-18. doi:10.1084/ jem.179.4.1109

6. Caux C, Vanbervliet B, Massacrier C, Dezutter-Dambuyant C, De Saint-Vis $\mathrm{B}$, Jacquet $\mathrm{C}$, et al. CD34+ hematopoietic progenitors from human cord blood differentiate along two independent dendritic cell pathways in response to GM-CSF+TNF alpha. J Exp Med (1996) 184:695-706. doi:10.1084/ jem.184.2.695

7. Palucka KA, Taquet N, Sanchez-Chapuis F, Gluckman JC. Dendritic cells as the terminal stage of monocyte differentiation. J Immunol (1998) 160:4587-95.

8. Xu Y, Zhan Y, Lew AM, Naik SH, Kershaw MH. Differential development of murine dendritic cells by GM-CSF versus Flt3 ligand has implications for inflammation and trafficking. J Immunol (2007) 179:7577-84. doi:10.4049/ jimmunol.179.11.7577

9. Randolph GJ, Inaba K, Robbiani DF, Steinman RM, Muller WA. Differentiation of phagocytic monocytes into lymph node dendritic cells in vivo. Immunity (1999) 11:753-61. doi:10.1016/S1074-7613(00)80149-1

10. Geissmann F, Jung S, Littman DR. Blood monocytes consist of two principal subsets with distinct migratory properties. Immunity (2003) 19:71-82. doi:10.1016/S1074-7613(03)00174-2

11. Serbina NV, Salazar-Mather TP, Biron CA, Kuziel WA, Pamer EG. TNF/iNOS-producing dendritic cells mediate innate immune defense against bacterial infection. Immunity (2003) 19:59-70. doi:10.1016/ S1074-7613(03)00171-7

12. Naik SH, Metcalf D, Van Nieuwenhuijze A, Wicks I, Wu L, O’Keeffe M, et al. Intrasplenic steady-state dendritic cell precursors that are distinct from monocytes. Nat Immunol (2006) 7:663-71. doi:10.1038/ni1340

13. Varol C, Landsman L, Fogg DK, Greenshtein L, Gildor B, Margalit R, et al. Monocytes give rise to mucosal, but not splenic, conventional dendritic cells. J Exp Med (2007) 204:171-80. doi:10.1084/jem.20061011

14. Bogunovic M, Ginhoux F, Helft J, Shang L, Hashimoto D, Greter M, et al. Origin of the lamina propria dendritic cell network. Immunity (2009) 31(3):513-25. doi:10.1016/j.immuni.2009.08.010

15. Varol C, Vallon-Eberhard A, Elinav E, Aychek T, Shapira Y, Luche H, et al. Intestinal lamina propria dendritic cell subsets have different origin and functions. Immunity (2009) 31:502-12. doi:10.1016/j.immuni.2009.06.025

16. Yona $\mathrm{S}$, Gordon S. From the reticulo-endothelial to mononuclear phagocyte system - the unaccounted years. Front Immunol (2015) 6:328. doi:10.3389/ fimmu.2015.00328

17. Diao J, Winter E, Cantin C, Chen W, Xu L, Kelvin D, et al. In situ replication of immediate dendritic cell (DC) precursors contributes to conventional DC homeostasis in lymphoid tissue. J Immunol (2006) 176:7196-206. doi:10.4049/jimmunol.176.12.7196

18. Naik SH, Sathe P, Park HY, Metcalf D, Proietto AI, Dakic A, et al. Development of plasmacytoid and conventional dendritic cell subtypes from single precursor cells derived in vitro and in vivo. Nat Immunol (2007) 8:1217-26. doi:10.1038/ni1522

19. Onai N, Obata-Onai A, Schmid MA, Ohteki T, Jarrossay D, Manz MG. Identification of clonogenic common Flt3+M-CSFR+ plasmacytoid and conventional dendritic cell progenitors in mouse bone marrow. Nat Immunol (2007) 8:1207-16. doi:10.1038/ni1518

20. Merad M, Sathe P, Helft J, Miller J, Mortha A. The dendritic cell lineage: ontogeny and function of dendritic cells and their subsets in the steady state and the inflamed setting. Annu Rev Immunol (2013) 31:563-604. doi:10.1146/ annurev-immunol-020711-074950

21. Saunders D, Lucas K, Ismaili J, Wu L, Maraskovsky E, Dunn A, et al. Dendritic cell development in culture from thymic precursor cells in the absence of granulocyte/macrophage colony-stimulating factor. J Exp Med (1996) 184:2185-96. doi:10.1084/jem.184.6.2185

22. Pulendran B, Banchereau J, Burkeholder S, Kraus E, Guinet E, Chalouni $\mathrm{C}$, et al. Flt3-ligand and granulocyte colony-stimulating factor mobilize distinct human dendritic cell subsets in vivo. J Immunol (2000) 165:566-72. doi:10.4049/jimmunol.165.1.566

23. Naik SH, Proietto AI, Wilson NS, Dakic A, Schnorrer P, Fuchsberger M, et al. Cutting edge: generation of splenic CD8+ and CD8- dendritic cell equivalents in Fms-like tyrosine kinase 3 ligand bone marrow cultures. J Immunol (2005) 174:6592-7. doi:10.4049/jimmunol.174.11.6592

24. Salomon B, Cohen JL, Masurier C, Klatzmann D. Three populations of mouse lymph node dendritic cells with different origins and dynamics. J Immunol (1998) 160:708-17.

25. McKenna HJ, Stocking KL, Miller RE, Brasel K, De Smedt T, Maraskovsky E, et al. Mice lacking flt3 ligand have deficient hematopoiesis affecting hematopoietic progenitor cells, dendritic cells, and natural killer cells. Blood (2000) 95:3489-97.

26. Karsunky H, Merad M, Cozzio A, Weissman IL, Manz MG. Flt3 ligand regulates dendritic cell development from Flt3+ lymphoid and myeloid-committed progenitors to Flt3+ dendritic cells in vivo. J Exp Med (2003) 198:305-13. doi:10.1084/jem.20030323

27. Waskow C, Liu K, Darrasse-Jeze G, Guermonprez P, Ginhoux F, Merad $\mathrm{M}$, et al. The receptor tyrosine kinase Flt3 is required for dendritic cell development in peripheral lymphoid tissues. Nat Immunol (2008) 9:676-83. doi:10.1038/ni.1615

28. Ginhoux F, Liu K, Helft J, Bogunovic M, Greter M, Hashimoto D, et al. The origin and development of nonlymphoid tissue CD103+ DCs. J Exp Med (2009) 206:3115-30. doi:10.1084/jem.20091756

29. Onai N, Kurabayashi K, Hosoi-Amaike M, Toyama-Sorimachi N, Matsushima K, Inaba $\mathrm{K}$, et al. A clonogenic progenitor with prominent plasmacytoid dendritic cell developmental potential. Immunity (2013) 38:943-57. doi:10.1016/j.immuni.2013.04.006

30. Hettinger J, Richards DM, Hansson J, Barra MM, Joschko AC, Krijgsveld J, et al. Origin of monocytes and macrophages in a committed progenitor. Nat Immunol (2013) 14:821-30. doi:10.1038/ni.2638

31. Breton G, Lee J, Zhou YJ, Schreiber JJ, Keler T, Puhr S, et al. Circulating precursors of human CD1c+ and CD141+ dendritic cells. J Exp Med (2015) 212:401-13. doi:10.1084/jem.20141441

32. Lee J, Breton G, Oliveira TY, Zhou YJ, Aljoufi A, Puhr S, et al. Restricted dendritic cell and monocyte progenitors in human cord blood and bone marrow. J Exp Med (2015) 212:385-99. doi:10.1084/jem.20141442

33. Ginhoux F, Greter M, Leboeuf M, Nandi S, See P, Gokhan S, et al. Fate mapping analysis reveals that adult microglia derive from primitive macrophages. Science (2010) 330:841-5. doi:10.1126/science.1194637

34. Schulz C, Gomez Perdiguero E, Chorro L, Szabo-Rogers H, Cagnard N, Kierdorf K, et al. A lineage of myeloid cells independent of Myb and hematopoietic stem cells. Science (2012) 336:86-90. doi:10.1126/science.1219179

35. Guilliams M, De Kleer I, Henri S, Post S, Vanhoutte L, De Prijck S, et al. Alveolar macrophages develop from fetal monocytes that differentiate into long-lived cells in the first week of life via GM-CSF. J Exp Med (2013) 210:1977-92. doi:10.1084/jem.20131199

36. Hashimoto D, Chow A, Noizat C, Teo P, Beasley MB, Leboeuf M, et al. Tissue-resident macrophages self-maintain locally throughout adult life with minimal contribution from circulating monocytes. Immunity (2013) 38:792-804. doi:10.1016/j.immuni.2013.04.004

37. Jakubzick C, Gautier EL, Gibbings SL, Sojka DK, Schlitzer A, Johnson TE, et al. Minimal differentiation of classical monocytes as they survey steady-state tissues and transport antigen to lymph nodes. Immunity (2013) 39:599-610. doi:10.1016/j.immuni.2013.08.007

38. Yona S, Kim KW, Wolf Y, Mildner A, Varol D, Breker M, et al. Fate mapping reveals origins and dynamics of monocytes and tissue macrophages under homeostasis. Immunity (2013) 38:79-91. doi:10.1016/j.immuni.2012.12.001

39. Gomez Perdiguero E, Klapproth K, Schulz C, Busch K, Azzoni E, Crozet L, et al. Tissue-resident macrophages originate from yolk-sac-derived erythro-myeloid progenitors. Nature (2015) 518:547-51. doi:10.1038/nature13989 
40. Ginhoux F, Jung S. Monocytes and macrophages: developmental pathways and tissue homeostasis. Nat Rev Immunol (2014) 14:392-404. doi:10.1038/ nri3671

41. Scott CL, Henri S, Guilliams M. Mononuclear phagocytes of the intestine, the skin, and the lung. Immunol Rev (2014) 262:9-24. doi:10.1111/imr.12220

42. Varol C, Mildner A, Jung S. Macrophages: development and tissue specialization. Annu Rev Immunol (2015) 33:643-75. doi:10.1146/ annurev-immunol-032414-112220

43. Hoeffel G, Wang Y, Greter M, See P, Teo P, Malleret B, et al. Adult Langerhans cells derive predominantly from embryonic fetal liver monocytes with a minor contribution of yolk sac-derived macrophages. J Exp Med (2012) 209(6):1167-81. doi:10.1084/jem.20120340

44. Hoeffel G, Chen J, Lavin Y, Low D, Almeida FF, See P, et al. C-myb(+) erythro-myeloid progenitor-derived fetal monocytes give rise to adult tissue-resident macrophages. Immunity (2015) 42:665-78. doi:10.1016/j. immuni.2015.03.011

45. Tamoutounour S, Henri S, Lelouard H, De Bovis B, De Haar C, Van Der Woude CJ, et al. CD64 distinguishes macrophages from dendritic cells in the gut and reveals the Th1-inducing role of mesenteric lymph node macrophages during colitis. Eur J Immunol (2012) 42(12):3150-66. doi:10.1002/ eji.201242847

46. Bain CC, Scott CL, Uronen-Hansson H, Gudjonsson S, Jansson O, Grip O, et al. Resident and pro-inflammatory macrophages in the colon represent alternative context-dependent fates of the same Ly6C(hi) monocyte precursors. Mucosal Immunol (2012) 6(3):498-510. doi:10.1038/mi.2012.89

47. Plantinga M, Guilliams M, Vanheerswynghels M, Deswarte K, BrancoMadeira F, Toussaint W, et al. Conventional and monocyte-derived CD11b $(+)$ dendritic cells initiate and maintain $\mathrm{T}$ helper 2 cell-mediated immunity to house dust mite allergen. Immunity (2013) 38:322-35. doi:10.1016/j. immuni.2012.10.016

48. Tamoutounour S, Guilliams M, Montanana Sanchis F, Liu H, Terhorst D, Malosse C, et al. Origins and functional specialization of macrophages and of conventional and monocyte-derived dendritic cells in mouse skin. Immunity (2013) 39:925-38. doi:10.1016/j.immuni.2013.10.004

49. Geurtsvankessel CH, Bergen IM, Muskens F, Boon L, Hoogsteden HC, Osterhaus AD, et al. Both conventional and interferon killer dendritic cells have antigen-presenting capacity during influenza virus infection. PLoS One (2009) 4:e7187. doi:10.1371/journal.pone.0007187

50. Janssen WJ, Barthel L, Muldrow A, Oberley-Deegan RE, Kearns MT, Jakubzick C, et al. Fas determines differential fates of resident and recruited macrophages during resolution of acute lung injury. Am J Respir Crit Care Med (2011) 184:547-60. doi:10.1164/rccm.201011-1891OC

51. Balan S, Ollion V, Colletti N, Chelbi R, Montanana-Sanchis F, Liu H, et al. Human XCR1+ dendritic cells derived in vitro from CD34+ progenitors closely resemble blood dendritic cells, including their adjuvant responsiveness, contrary to monocyte-derived dendritic cells. J Immunol (2014) 193:1622-35. doi:10.4049/jimmunol.1401243

52. Desch AN, Gibbings SL, Clambey ET, Janssen WJ, Slansky JE, Kedl RM, et al. Dendritic cell subsets require cis-activation for cytotoxic CD8 T-cell induction. Nat Commun (2014) 5:4674. doi:10.1038/ncomms5674

53. Guilliams M, Ginhoux F, Jakubzick C, Naik SH, Onai N, Schraml BU, et al. Dendritic cells, monocytes and macrophages: a unified nomenclature based on ontogeny. Nat Rev Immunol (2014) 14:571-8. doi:10.1038/nri3712

54. Xue J, Schmidt SV, Sander J, Draffehn A, Krebs W, Quester I, et al. Transcriptome-based network analysis reveals a spectrum model of human macrophage activation. Immunity (2014) 40:274-88. doi:10.1016/j. immuni.2014.01.006

55. Robbins SH, Walzer T, Dembele D, Thibault C, Defays A, Bessou G, et al. Novel insights into the relationships between dendritic cell subsets in human and mouse revealed by genome-wide expression profiling. Genome Biol (2008) 9:R17. doi:10.1186/gb-2008-9-1-r17

56. Crozat K, Guiton R, Guilliams M, Henri S, Baranek T, Schwartz-Cornil I, et al. Comparative genomics as a tool to reveal functional equivalences between human and mouse dendritic cell subsets. Immunol Rev (2010) 234:177-98. doi:10.1111/j.0105-2896.2009.00868.x

57. Guilliams M, Henri S, Tamoutounour S, Ardouin L, Schwartz-Cornil I, Dalod $\mathrm{M}$, et al. From skin dendritic cells to a simplified classification of human and mouse dendritic cell subsets. Eur J Immunol (2010) 40:2089-94. doi:10.1002/ eji. 201040498

58. Miller MA, Feng XJ, Li G, Rabitz HA. Identifying biological network structure, predicting network behavior, and classifying network state with high dimensional model representation (HDMR). PLoS One (2012) 7:e37664. doi:10.1371/journal.pone.0037664

59. Vu Manh TP, Marty H, Sibille P, Le Vern Y, Kaspers B, Dalod M, et al. Existence of conventional dendritic cells in gallus gallus revealed by comparative gene expression profiling. J Immunol (2014) 192(10):4510-7. doi:10.4049/ jimmunol.1303405

60. Vu Manh TP, Bertho N, Hosmalin A, Schwartz-Cornil I, Dalod M. Investigating evolutionary conservation of dendritic cell subset identity and functions. Front Immunol (2015) 6:260. doi:10.3389/fimmu.2015.00260

61. Vu Manh TP, Elhmouzi-Younes J, Urien C, Ruscanu S, Jouneau L, Bourge $\mathrm{M}$, et al. Defining mononuclear phagocyte subset homology across several distant warm-blooded vertebrates through comparative transcriptomics. Front Immunol (2015) 6:299. doi:10.3389/fimmu.2015.00299

62. Durand M, Segura E. The known unknowns of the human dendritic cell network. Front Immunol (2015) 6:129. doi:10.3389/fimmu.2015.00129

63. Reynolds G, Haniffa M. Human and mouse mononuclear phagocyte networks: a tale of two species? Front Immunol (2015) 6:330. doi:10.3389/ fimmu.2015.00330

64. Bachem A, Guttler S, Hartung E, Ebstein F, Schaefer M, Tannert A, et al. Superior antigen cross-presentation and XCR1 expression define human CD11c+CD141+ cells as homologues of mouse CD8+ dendritic cells. J Exp Med (2010) 207:1273-81. doi:10.1084/jem.20100348

65. Contreras V, Urien C, Guiton R, Alexandre Y, Vu Manh TP, Andrieu T, et al. Existence of CD8alpha-like dendritic cells with a conserved functional specialization and a common molecular signature in distant mammalian species. J Immunol (2010) 185:3313-25. doi:10.4049/jimmunol.1000824

66. Crozat K, Guiton R, Contreras V, Feuillet V, Dutertre CA, Ventre E, et al. The XC chemokine receptor 1 is a conserved selective marker of mammalian cells homologous to mouse CD8alpha+ dendritic cells. J Exp Med (2010) 207:1283-92. doi:10.1084/jem.20100223

67. Crozat K, Tamoutounour S, Vu Manh TP, Fossum E, Luche H, Ardouin L, et al. Cutting edge: expression of XCR1 defines mouse lymphoid-tissue resident and migratory dendritic cells of the CD8alpha+ type. JImmunol (2011) 187:4411-5. doi:10.4049/jimmunol.1101717

68. Bachem A, Hartung E, Guttler S, Mora A, Zhou X, Hegemann A, et al. Expression of XCR1 characterizes the Batf3-dependent lineage of dendritic cells capable of antigen cross-presentation. Front Immunol (2012) 3:214. doi:10.3389/fimmu.2012.00214

69. Becker M, Guttler S, Bachem A, Hartung E, Mora A, Jakel A, et al. Ontogenic, phenotypic, and functional characterization of XCR1(+) dendritic cells leads to a consistent classification of intestinal dendritic cells based on the expression of XCR1 and SIRPalpha. Front Immunol (2014) 5:326. doi:10.3389/ fimmu.2014.00326

70. Gurka S, Hartung E, Becker M, Kroczek RA. Mouse conventional dendritic cells can be universally classified based on the mutually exclusive expression of XCR1 and SIRPalpha. Front Immunol (2015) 6:35. doi:10.3389/ fimmu.2015.00035

71. Grajales-Reyes GE, Iwata A, Albring J, Wu X, Tussiwand R, Kc W, et al. Batf3 maintains autoactivation of Irf8 for commitment of a CD8alpha conventional DC clonogenic progenitor. Nat Immunol (2015) 16(7):708-17. doi:10.1038/ ni.3197

72. Schlitzer A, Sivakamasundari V, Chen J, Sumatoh HR, Schreuder J, Lum J, et al. Identification of $\mathrm{CDC1}$ - and $\mathrm{CDC} 2$-committed DC progenitors reveals early lineage priming at the common DC progenitor stage in the bone marrow. Nat Immunol (2015) 16(7):718-28. doi:10.1038/ni.3200

73. Hildner K, Edelson BT, Purtha WE, Diamond M, Matsushita H, Kohyama $\mathrm{M}$, et al. Batf3 deficiency reveals a critical role for CD8alpha+ dendritic cells in cytotoxic T cell immunity. Science (2008) 322:1097-100. doi:10.1126/ science. 1164206

74. Edelson BT, Kc W, Juang R, Kohyama M, Benoit LA, Klekotka PA, et al. Peripheral CD103+ dendritic cells form a unified subset developmentally related to CD8alpha+ conventional dendritic cells. J Exp Med (2010) 207:823-36. doi:10.1084/jem.20091627 
75. Hacker C, Kirsch RD, Ju XS, Hieronymus T, Gust TC, Kuhl C, et al. Transcriptional profiling identifies Id 2 function in dendritic cell development. Nat Immunol (2003) 4:380-6. doi:10.1038/ni903

76. Jackson JT, Hu Y, Liu R, Masson F, D’Amico A, Carotta S, et al. Id2 expression delineates differential checkpoints in the genetic program of CD8alpha+ and CD103+ dendritic cell lineages. EMBO J (2011) 30:2690-704. doi:10.1038/ emboj.2011.163

77. Kashiwada M, Pham NL, Pewe LL, Harty JT, Rothman PB. NFIL3/E4BP4 is a key transcription factor for CD8alpha(+) dendritic cell development. Blood (2011) 117:6193-7. doi:10.1182/blood-2010-07-295873

78. Schiavoni G, Mattei F, Sestili P, Borghi P, Venditti M, Morse HC III, et al. ICSBP is essential for the development of mouse type I interferon-producing cells and for the generation and activation of CD8alpha(+) dendritic cells. J Exp Med (2002) 196:1415-25. doi:10.1084/jem.20021263

79. Tamura T, Tailor P, Yamaoka K, Kong HJ, Tsujimura H, O'Shea JJ, et al. IFN regulatory factor- 4 and -8 govern dendritic cell subset development and their functional diversity. J Immunol (2005) 174:2573-81. doi:10.4049/ jimmunol.174.5.2573

80. Tailor P, Tamura T, Morse HC III, Ozato K. The BXH2 mutation in IRF8 differentially impairs dendritic cell subset development in the mouse. Blood (2008) 111:1942-5. doi:10.1182/blood-2007-07-100750

81. Wu L, D’Amico A, Winkel KD, Suter M, Lo D, Shortman K. RelB is essential for the development of myeloid-related CD8alpha- dendritic cells but not of lymphoid-related CD8alpha+ dendritic cells. Immunity (1998) 9:839-47. doi:10.1016/S1074-7613(00)80649-4

82. Caton ML, Smith-Raska MR, Reizis B. Notch-RBP-J signaling controls the homeostasis of CD8- dendritic cells in the spleen. J Exp Med (2007) 204:1653-64. doi:10.1084/jem.20062648

83. SuzukiS,HonmaK,MatsuyamaT,SuzukiK, ToriyamaK,AkitoyoI,etal.Critical roles of interferon regulatory factor 4 in CD11bhighCD8alpha- dendritic cell development. Proc Natl Acad Sci U S A (2004) 101:8981-6. doi:10.1073/pnas. 0402139101

84. Persson EK, Uronen-Hansson H, Semmrich M, Rivollier A, Hagerbrand $\mathrm{K}$, Marsal J, et al. IRF4 transcription-factor-dependent CD103CD11b dendritic cells drive mucosal T helper 17 cell differentiation. Immunity (2013) 38(5):958-69. doi:10.1016/j.immuni.2013.03.009

85. Schlitzer A, Mcgovern N, Teo P, Zelante T, Atarashi K, Low D, et al. IRF4 transcriptionfactor-dependentCD11b+dendriticcellsinhumanandmousecontrol mucosal IL-17 cytokine responses. Immunity (2013) 38:970-83. doi:10.1016/ j.immuni.2013.04.011

86. Cisse B, Caton ML, Lehner M, Maeda T, Scheu S, Locksley R, etal. Transcription factor E2-2 is an essential and specific regulator of plasmacytoid dendritic cell development. Cell (2008) 135:37-48. doi:10.1016/j.cell.2008.09.016

87. Ghosh HS, Cisse B, Bunin A, Lewis KL, Reizis B. Continuous expression of the transcription factor e2-2 maintains the cell fate of mature plasmacytoid dendritic cells. Immunity (2010) 33:905-16. doi:10.1016/j.immuni.2010. 11.023

88. Benson MJ, Pino-Lagos K, Rosemblatt M, Noelle RJ. All-trans retinoic acid mediates enhanced $T$ regcellgrowth, differentiation, and gut homing in the face of high levels of co-stimulation. J Exp Med (2007) 204:1765-74. doi:10.1084/ jem.20070719

89. Coombes JL, Siddiqui KR, Arancibia-Carcamo CV, Hall J, Sun CM, Belkaid Y, et al. A functionally specialized population of mucosal CD103+ DCs induces Foxp3+ regulatory T cells via a TGF-beta and retinoic acid-dependent mechanism. J Exp Med (2007) 204:1757-64. doi:10.1084/jem.20070590

90. Sun CM, Hall JA, Blank RB, Bouladoux N, Oukka M, Mora JR, et al. Small intestine lamina propria dendritic cells promote de novo generation of Foxp $3 \mathrm{~T}$ reg cells via retinoic acid. JExp Med (2007) 204:1775-85. doi:10.1084/jem.200 70602

91. Guilliams M, Crozat K, Henri S, Tamoutounour S, Grenot P, Devilard E, et al. Skin-draining lymph nodes contain dermis-derived CD103(-) dendritic cells that constitutively produce retinoic acid and induce Foxp3(+) regulatory $\mathrm{T}$ cells. Blood (2010) 115:1958-68. doi:10.1182/blood-2009-09-245274

92. Gatto D, Wood K, Caminschi I, Murphy-Durland D, Schofield P, Christ D, et al. The chemotactic receptor EBI2 regulates the homeostasis, localization and immunological function of splenic dendritic cells. Nat Immunol (2013) 14:446-53. doi:10.1038/ni.2555

93. Lewis KL, Caton ML, Bogunovic M, Greter M, Grajkowska LT, Ng D, et al. Notch2 receptor signaling controls functional differentiation of dendritic cells in the spleen and intestine. Immunity (2011) 35:780-91. doi:10.1016/j. immuni.2011.08.013

94. Satpathy AT, Briseno CG, Lee JS, Ng D, Manieri NA, Kc W, et al. Notch2dependent classical dendritic cells orchestrate intestinal immunity to attaching-and-effacing bacterial pathogens. Nat Immunol (2013) 14:937-48. doi:10.1038/ni.2679

95. Tussiwand R, Everts B, Grajales-Reyes GE, Kretzer NM, Iwata A, Bagaitkar $\mathrm{J}$, et al. Klf4 expression in conventional dendritic cells is required for $\mathrm{T}$ helper 2 cell responses. Immunity (2015) 42:916-28. doi:10.1016/j.immuni. 2015.04.017

96. Gao Y, Nish SA, Jiang R, Hou L, Licona-Limon P, Weinstein JS, et al. Control of T helper 2 responses by transcription factor IRF4-dependent dendritic cells. Immunity (2013) 39:722-32. doi:10.1016/j.immuni.2013.08.028

97. Chou DB, Sworder B, Bouladoux N, Roy CN, Uchida AM, Grigg M, et al. Stromal-derived IL-6 alters the balance of myeloerythroid progenitors during Toxoplasma gondii infection. J Leukoc Biol (2012) 92:123-31. doi:10.1189/ jlb.1011527

98. Chorro L, Sarde A, Li M, Woollard KJ, Chambon P, Malissen B, et al. Langerhans cell (LC) proliferation mediates neonatal development, homeostasis, and inflammation-associated expansion of the epidermal LC network. J Exp Med (2009) 206:3089-100. doi:10.1084/jem.20091586

99. Jaitin DA, Kenigsberg E, Keren-Shaul H, Elefant N, Paul F, Zaretsky I, et al. Massively parallel single-cell RNA-seq for marker-free decomposition of tissues into cell types. Science (2014) 343:776-9. doi:10.1126/science.1247651

100. Zigmond E, Samia-Grinberg S, Pasmanik-Chor M, Brazowski E, Shibolet O, Halpern $\mathrm{Z}$, et al. Infiltrating monocyte-derived macrophages and resident Kupffer cells display different ontogeny and functions in acute liver injury. J Immunol (2014) 193(1):344-53. doi:10.4049/jimmunol.1400574

101. Ajami B, Bennett JL, Krieger C, Tetzlaff W, Rossi FM. Local self-renewal can sustain CNS microglia maintenance and function throughout adult life. Nat Neurosci (2007) 10:1538-43. doi:10.1038/nn2014

102. Ajami B, Bennett JL, Krieger C, Mcnagny KM, Rossi FM. Infiltrating monocytes trigger EAE progression, but do not contribute to the resident microglia pool. Nat Neurosci (2011) 14:1142-9. doi:10.1038/nn.2887

103. Yamasaki R, Lu H, Butovsky O, Ohno N, Rietsch AM, Cialic R, et al. Differential roles of microglia and monocytes in the inflamed central nervous system. J Exp Med (2014) 211:1533-49. doi:10.1084/jem.20132477

104. Gautier EL, Shay T, Miller J, Greter M, Jakubzick C, Ivanov S, et al. Geneexpression profiles and transcriptional regulatory pathways that underlie the identity and diversity of mouse tissue macrophages. Nat Immunol (2012) 13:1118-28. doi:10.1038/ni.2419

105. Lavin Y, Winter D, Blecher-Gonen R, David E, Keren-Shaul H, Merad M, et al. Tissue-resident macrophage enhancer landscapes are shaped by the local microenvironment. Cell (2014) 159:1312-26. doi:10.1016/j.cell.2014.11.018

106. Murray PJ, Allen JE, Biswas SK, Fisher EA, Gilroy DW, Goerdt S, et al. Macrophage activation and polarization: nomenclature and experimental guidelines. Immunity (2014) 41:14-20. doi:10.1016/j.immuni.2014.06.008

107. Jha AK, Huang SC, Sergushichev A, Lampropoulou V, Ivanova Y, Loginicheva E, et al. Network integration of parallel metabolic and transcriptional data reveals metabolic modules that regulate macrophage polarization. Immunity (2015) 42:419-30. doi:10.1016/j.immuni.2015.02.005

108. Siddiqui KR, Laffont S, Powrie F. E-cadherin marks a subset of inflammatory dendritic cells that promote T cell-mediated colitis. Immunity (2010) 32:557-67. doi:10.1016/j.immuni.2010.03.017

109. Guilliams M, Movahedi K, Bosschaerts T, Vandendriessche T, Chuah MK, Herin M, et al. IL-10 dampens TNF/inducible nitric oxide synthase-producing dendritic cell-mediated pathogenicity during parasitic infection. J Immunol (2009) 182:1107-18. doi:10.4049/jimmunol.182.2.1107

110. Kuipers H, Soullie T, Hammad H, Willart M, Kool M, Hijdra D, et al. Sensitization by intratracheally injected dendritic cells is independent of antigen presentation by host antigen-presenting cells. J Leukoc Biol (2009) 85:64-70. doi:10.1189/jlb.0807519

111. Cheong C, Matos I, Choi JH, Dandamudi DB, Shrestha E, Longhi MP, et al Microbial stimulation fully differentiates monocytes to DC-SIGN/CD209(+) dendritic cells for immune T cell areas. Cell (2010) 143:416-29. doi:10.1016/j. cell.2010.09.039

112. Shalek AK, Satija R, Adiconis X, Gertner RS, Gaublomme JT, Raychowdhury $\mathrm{R}$, et al. Single-cell transcriptomics reveals bimodality in expression and splicing in immune cells. Nature (2013) 498:236-40. doi:10.1038/nature12172 
113. Ohl L, Mohaupt M, Czeloth N, Hintzen G, Kiafard Z, Zwirner J, et al. CCR7 governs skin dendritic cell migration under inflammatory and steady-state conditions. Immunity (2004) 21:279-88. doi:10.1016/j.immuni.2004.06.014

114. Jang MH, Sougawa N, Tanaka T, Hirata T, Hiroi T, Tohya K, et al. CCR7 is critically important for migration of dendritic cells in intestinal lamina propria to mesenteric lymph nodes. J Immunol (2006) 176:803-10. doi:10.4049/ jimmunol.176.2.803

115. Guilliams M, Malissen B. A death notice for in-vitro-generated GM-CSF dendritic cells? Immunity (2015) 42:988-90. doi:10.1016/j.immuni.2015.05.020

116. Helft J, Bottcher J, Chakravarty P, Zelenay S, Huotari J, Schraml BU, et al. GM-CSF mouse bone marrow cultures comprise a heterogeneous population of CD11c(+)MHCII(+) macrophages and dendritic cells. Immunity (2015) 42:1197-211. doi:10.1016/j.immuni.2015.05.018

117. Wimmers F, Schreibelt G, Skold AE, Figdor CG, De Vries IJ. Paradigm shift in dendritic cell-based immunotherapy: from in vitro generated monocyte-derived DCs to naturally circulating DC subsets. Front Immunol (2014) 5:165. doi:10.3389/fimmu.2014.00165

118. Poulin LF, Salio M, Griessinger E, Anjos-Afonso F, Craciun L, Chen JL, et al. Characterization of human DNGR-1+ BDCA3+ leukocytes as putative equivalents of mouse CD8alpha+ dendritic cells. J Exp Med (2010) 207:1261-71. doi:10.1084/jem.20092618

119. Bain CC, Bravo-Blas A, Scott CL, Gomez Perdiguero E, Geissmann F, Henri $\mathrm{S}$, et al. Constant replenishment from circulating monocytes maintains the macrophage pool in the intestine of adult mice. Nat Immunol (2014) 15:929-37. doi:10.1038/ni.2967

120. Epelman S, Lavine KJ, Beaudin AE, Sojka DK, Carrero JA, Calderon B, et al. Embryonic and adult-derived resident cardiac macrophages are maintained through distinct mechanisms at steady state and during inflammation. Immunity (2014) 40:91-104. doi:10.1016/j.immuni.2013.11.019

121. Molawi K, Wolf Y, Kandalla PK, Favret J, Hagemeyer N, Frenzel K, et al. Progressive replacement of embryo-derived cardiac macrophages with age. J Exp Med (2014) 211:2151-8. doi:10.1084/jem.20140639

122. Swirski FK, Nahrendorf M, Etzrodt M, Wildgruber M, Cortez-Retamozo $\mathrm{V}$, Panizzi P, et al. Identification of splenic reservoir monocytes and their deployment to inflammatory sites. Science (2009) 325:612-6. doi:10.1126/ science. 1175202

123. Schraml BU, Van Blijswijk J, Zelenay S, Whitney PG, Filby A, Acton SE, et al. Genetic tracing via DNGR-1 expression history defines dendritic cells as a hematopoietic lineage. Cell (2013) 154:843-58. doi:10.1016/j.cell.2013. 07.014

124. Poltorak MP, Schraml BU. Fate mapping of dendritic cells. Front Immunol (2015) 6:199. doi:10.3389/fimmu.2015.00199

Conflict of Interest Statement: The authors declare that the research was conducted in the absence of any commercial or financial relationships that could be construed as a potential conflict of interest.

Copyright (C) 2015 Guilliams and van de Laar. This is an open-access article distributed under the terms of the Creative Commons Attribution License (CC BY). The use, distribution or reproduction in other forums is permitted, provided the original author(s) or licensor are credited and that the original publication in this journal is cited, in accordance with accepted academic practice. No use, distribution or reproduction is permitted which does not comply with these terms. 